\title{
NEONATAL AND SENESCENT CHANGES IN L-AROMATIC AMINO ACID DECARBOXYLASE AND MONOAMINE OXIDASE ACTIVITIES IN KIDNEY, LIVER, BRAIN AND HEART OF THE RAT
}

\author{
Chiyoko INAGAKI and Chikako TANAKA \\ Department of Phamacology, Faculty of Medicine, Kyoto University, Kyoto 606, Japan
}

Accepted November 16, 1973

\begin{abstract}
The activities of AADC and MAO were measured in kidney, liver, brain and heart of the rat at neonatal to senescent stages. Rapid neonatal increase to adult level in the specific activity of AADC was observed in the kidney, liver and brain. The total activity of AADC per organ continued to increase in the brain for 3 weeks after birth and for 20 weeks in the kidney and liver. In the heart, the specific activity of AADC increased up to the 10th day after birth and decreased to the mature level during the next 10 days. Senescent decreases both in specific and total activities of AADC were observed in all organs examined. Neonatal increment to adult level in the specific or total activities of MAO in kidney, liver and brain was observed. Senescent decrement in specific and total MAO activities was demonstrated in the kidney, while significant changes in liver and brain wore not observed. The MAO activity in heart continued to increase in linear fashion for 70 weeks after birth. The concentration of $5 \mathrm{HT}$ in kidney, liver and brain of the 10 day-old rats was much less than that in the adult. Senescent decreasc of 5HT contents was not evident in any organ examined. These findings suggest the age-related change of physiological condition of amine metabolism.
\end{abstract}

The age-related change in monoamine metabolism has heen discussed as a possible subclinical status of age-related neurologic disorders such as Parkinson's disease found among middle-aged or aged people (1). Further, therapcutic use of L-dihydroxyphenylalanine (L-DOPA) (per os) in treatment of Parkinson's disease has thrown light on the amine precursor metabolism in whole body as L-aromatic amino acid decarboxylase (AADC) and monoamine oxidase (MAO), which catalyze the synthesis of amine from the precursor aromatic amino acid and catabolism of annine, are widely distributed in animal tissues (2) and human liver, kidney, heart, lung and brain $(3,4)$. This age-related change of monoamine metabolism in whole boly is likely to exist with administration of 5-hydroxytryptophan (5HTP) in the treatment of mongolism (5), in which the dosage of $5 \mathrm{HTP}$ must be increased along with advancement in the patient's age in order to be effective. Thus the age-related change in AADC and MAO activitics, not only in the brain but also in peripheral organs, appear to be significant in relation to age-related physiological state of amine metabolism and therapy with amine precursors.

\section{MATERIALS AND METHODS}

Wistar strain rats at zero day (on the day of birth), 5 days, 10 days, 21 days, 6 weeks, 20 weeks and over-70 wceks of age wete used. Pregnant rats and 3 week-old rats (pur- 
chased) were housed in the laboratory. Newborn rats within 12 hours after birth were used as zero day rats. Categorized as 70-week-old rats were those from 72-94 weeks of age.

All rats were sacrificed by decapitation. Kidneys, liver, brain and heart were removed, weighed and homogenized in 9 volumes of $25 \mathrm{mM}$ Tris- $\mathrm{HCl}(\mathrm{pH} \mathrm{7.4)}$ with Teflonglass homogenizer. The homogenate was centrifuged at $12,000 \times \mathrm{g}$ (RC2-B Sorvall SS-34 rotor, $10,000 \mathrm{rpm}$ ) for $20 \mathrm{~min}$ at $4^{\circ} \mathrm{C}$. The supernatant fraction was assayed for AADC activity as described by Lovenberg (6). The pellet was re-homogenized in $0.9 \% \mathrm{KCl}$ and used as a particulate fraction. MAO activity was measured with this preparation by the method of Wurtman et al. (7).

Protein concentration was determined as described by Lowry et al. (8), using bovine serum albumin as a standard.

The levels of $5 \mathrm{HT}$ in tissues were measured by the method of Bogdanski et al. (9).

\section{RESULTS}

Weight and protein content of tissues

Rapid increase in tissue weight up to the 21 st day after birth was observed in the organs examined. Protein content of soluble or particulate fraction also increased rapidly during

TABI.E. 1. Tissue weight and protein content of soluble or particulate fraction.

\begin{tabular}{|c|c|c|c|c|c|c|}
\hline & & 10 days ${ }^{a)}$ & 21 days & $\begin{array}{c}\text { Age } \\
6 \text { weeks }\end{array}$ & 20 weeks & over 70 weeks \\
\hline \multirow[t]{3}{*}{ Kidney } & Tissue weight $(\mathrm{g})$ & $\begin{array}{ll} & 0.19 \\
+ & 0.01 * *\end{array}$ & $\begin{aligned} & 1.31 \\
\therefore & 0.06\end{aligned}$ & $\begin{array}{r}1.85 \\
+\quad 0.06\end{array}$ & $\begin{array}{r}3.00 \\
\therefore \quad 0.14\end{array}$ & $\begin{array}{r}3.65 \\
\therefore=0.39\end{array}$ \\
\hline & $\begin{array}{l}\text { Protein (mg) } \\
\text { soluble fr. }\end{array}$ & $\begin{array}{c}10.85 \\
0.92^{\text {** }}\end{array}$ & $\begin{array}{r}70.06 \\
+\quad 3.09\end{array}$ & $\begin{array}{r}136.3 \\
-\quad 8.9\end{array}$ & $\begin{array}{r}272.8 \\
+\quad 18.3\end{array}$ & $\begin{array}{r}295.7 \\
\pm \quad 48.8\end{array}$ \\
\hline & particulate fr. & $\begin{array}{l}5.17 \\
1.15^{* *}\end{array}$ & $\begin{array}{l}106.62 \\
t=11.26\end{array}$ & & $\begin{array}{r}167.0 \\
1 \quad 33.4\end{array}$ & $\begin{array}{r}162.9 \\
+\quad 46.0\end{array}$ \\
\hline \multirow[t]{3}{*}{ Liver } & Tissue weight $(\mathrm{g})$ & $\begin{array}{l}0.42 \\
0.05^{* *}\end{array}$ & $\begin{array}{r}5.55 \\
\pm 0.20\end{array}$ & $\begin{array}{r}9.82 \\
1.27\end{array}$ & $\begin{array}{r}15.87 \\
上 \quad 0.57\end{array}$ & $\begin{array}{r}16.77 \\
: \quad 0.36\end{array}$ \\
\hline & $\begin{array}{l}\text { Protein (mg) } \\
\text { soluble fr. }\end{array}$ & $\begin{aligned} & 31.76 \\
-: & 2.34 * *\end{aligned}$ & $\begin{array}{r}405.0 \\
+15.6\end{array}$ & $\begin{array}{r}794.3 \\
\pm 74.3\end{array}$ & $\begin{array}{r}1612 \\
\pm 74\end{array}$ & $\begin{array}{r}1643 \\
+\quad 183\end{array}$ \\
\hline & particulate fr. & $\begin{aligned} & 35.02 \\
- & 10.20^{* *}\end{aligned}$ & $\begin{array}{r}402.0 \\
\pm 62.0\end{array}$ & $-\cdots$ & $\begin{array}{r}976 \\
+\quad 199\end{array}$ & $\begin{array}{r}967 \\
\pm 262\end{array}$ \\
\hline \multirow[t]{3}{*}{ Brain } & Tissue weight $(\mathrm{g})$ & $\begin{array}{l}0.71 \\
+0.03^{*} *\end{array}$ & $\begin{array}{r}1.66 \\
+\quad 0.03\end{array}$ & $\begin{array}{r}1.65 \\
+\quad 0.04\end{array}$ & $\begin{array}{r}1.80 \\
1.0 .06\end{array}$ & $\begin{array}{r}2.00 \\
+\quad 0.10\end{array}$ \\
\hline & $\begin{array}{l}\text { Protein (mg) } \\
\text { soluble fr. }\end{array}$ & $\begin{aligned} & 28.27 \\
& \therefore \quad 1.61 * *\end{aligned}$ & $\begin{array}{r}71.23 \\
1.2 .97\end{array}$ & $\begin{array}{r}73.85 \\
\because \quad 6.36\end{array}$ & $\begin{array}{r}74.53 \\
\therefore \quad 6.13\end{array}$ & $\begin{array}{r}70.27 \\
: \quad 8.91\end{array}$ \\
\hline & particulate fr. & $\begin{array}{r}23.35 \\
3.52^{* *}\end{array}$ & $\begin{array}{r}79.98 \\
-\div \quad 4.26\end{array}$ & $-\cdots$ & $\begin{array}{r}81.72 \\
+\quad 10.00\end{array}$ & $\begin{array}{r}75.10 \\
+\quad 4.90\end{array}$ \\
\hline \multirow[t]{3}{*}{ Heart } & Tissue weight (g) & $\begin{aligned} & 0.16 \\
= & 0.00^{* *}\end{aligned}$ & $\begin{array}{r}0.51 \\
\pm 0.03\end{array}$ & $\begin{array}{r}0.80 \\
=0.03\end{array}$ & $\begin{array}{r}1.33 \\
\pm \quad 0.04\end{array}$ & $\begin{array}{r}1.56 \\
+\quad 0.16\end{array}$ \\
\hline & $\begin{array}{l}\text { Protein (mg) } \\
\text { soluble fr. }\end{array}$ & $\begin{aligned} & 4.40 \\
= & 0.30^{* * *}\end{aligned}$ & $\begin{array}{r}24.23 \\
\pm \quad 2.27\end{array}$ & $\begin{array}{r}40.46 \\
\doteq 2.73\end{array}$ & $\begin{array}{r}92.86 \\
+\quad 14.12\end{array}$ & $\begin{array}{r}95.95 \\
+12.57\end{array}$ \\
\hline & particulate fr. & $\begin{aligned} & 15.97 \\
= & 3.20^{* * *}\end{aligned}$ & $\begin{array}{r}25.14 \\
-\quad 1.35\end{array}$ & - & $\begin{array}{r}61.56 \\
+\quad 10.29\end{array}$ & $\begin{array}{r}56.69 \\
+\quad 8.15\end{array}$ \\
\hline
\end{tabular}

means \pm S.E. of values from 6 to 8 rats.

a) means \pm S.E. of 3-4 determination from 9 to 12 rats.

** : $\mathrm{p}<0.01$, as compared to the corresponding value at 20 weeks of age. 
this period. From this time on, tissue weight and protcin content of the fractions continued to increase gradually in the kidney, liver and heart. In the brain, minimum increase in tissue weight with no change in protein content were characteristic. After 20 weeks, slightly increasing tissue weight with no increase in protein contents was observed in kidney, liver, brain and heart. Data are outlined in Table 1.

Specific activity of $A A D C$

Specific activities of AADC in the supernatant fraction of tissue homogenates at various ages are shown in Fig. I. In the kidney, liver and brain, the specific activity of this enzyme was low at 0 day of age as compared to that at 20 weeks of age, and was observed to increase during 3 weeks after birth. The rate of increase in kidney AADC activity was approx. three times during the first 10 days, approx. four times for the next 10 days, or approx. 10 times during 20 days after birth. After the 20th day the specific activity of this enzyme in the kidney decreased along with age. In liver, the rate of increase was slight during the first 10 days and was most rapid for the next 10 days. This enzyme activity decreased in rats over 70 weeks as compared to that at 20 weeks of age. In the brain the specific enzyme activity remained unchanged during the first 10 days, then slightly increased for the next 10 days. A plateau of enzyme activity was observed during the period from 3 to 20 weeks, however, the decrease also appeared in the brain at the over 70 week stage. The specific activity of AADC in heart showed a curve dissimilar to those in other tissues. In rats at the day of birth, the highest activity of AADC was revealed in the heart, among the organs ex-

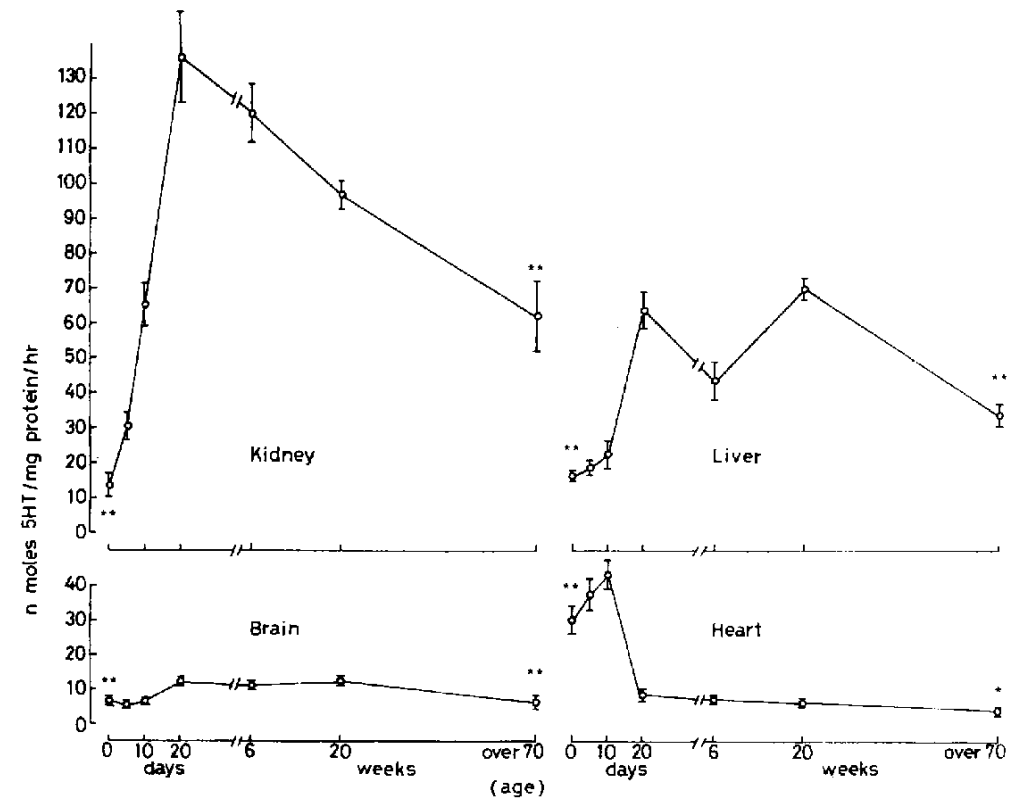

FIs. 1. Specific activity of L-aromatic amino acid decarboxylase (AADC) in soluble fractions of rat tissue homogenates. AADC was assayed under an excess co-factor condition using 5HTP as a substrate. Each point represents the mean S.E. of 8 to 15 different animals, ${ }^{* *} p<0.01$, ${ }^{*} p<0.05$, n.s. : non-significant, as compared to the corresponding value at 20 weeks of age. 
amined. This enzyme activity which increased gradually during 10 neonatal days, decreased rapidly to the mature level during the next 10 days. This mature level was approx. onethird that of the neonatal level, and was even lower over 70 weeks of age.



Fici. 2. Tolal activity of AADC in rat tissues. For the estimation of total activity, specific activity was multiplied by the value of protein content of soluble fraction. Each point represents the mean $\perp$ S.E. of 8 to 15 different animals. **p $0.01, * \mathrm{p}<0.05$, n.s. : non-significant, as compared to the corresponding value at 20 weeks of age.

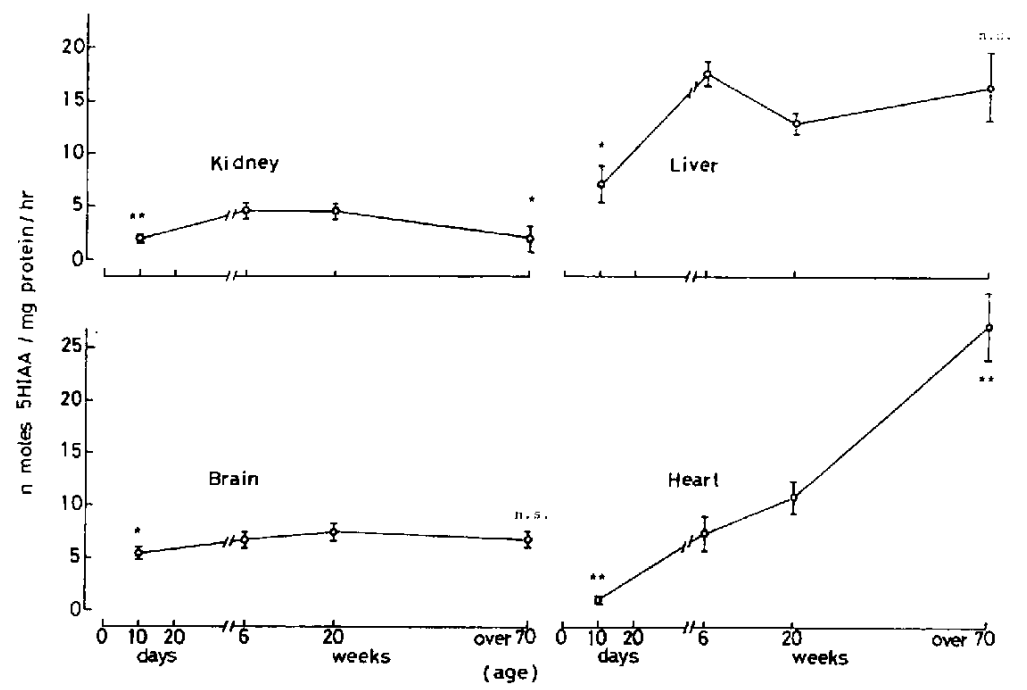

Fici. 3. Specific activity of monvamine oxidase (MAO) in particulate fractions of rat tissue homogenates. Each point represents the mean \pm S.E. of 6 to 8 different animals. ** ${ }^{* *} 0.01, * p<0.05$, n.s. : non-significant, as compared to the corresponding value at 20 wecks of age. 


\section{Total activity of $A A D C$}

The AADC activity per organ was calculated as the total activity of AADC as shown in Fig. 2. The total activities of this enzyme revealed rapid increases in kidney, tiver and heart by the 20 th week, and in brain by the 3 rd week. These increases coincided with those in specific activities, and with those in protein contents per organ which continued unchanged after this period, while the total AADC activities decreased at the over 70 week stage.

\section{Specific activity of MAO}

The specific activity of MAO in the particulate fraction of tissue homogenate was measured in the various stages (Fig. 3). Neonatal increment in the specific activity of this enzyme was observed in all tissues examined. Over 70 weeks of age a slight decrease in the specific activity of this enzyme was observed in kidney, while there was no significant change in liver and brain, yet a marked increase in the heart was revealed.

\section{Total activity of $M A O$}

Early postnatal increase in the total activity of MAO in particulate fractions was general and corresponded to the increase in protein contents (Fig. 4). Total activity of this enzyme in the brain, kidney and liver was highest at the 20th week. In the over 70 week stage this was slightly reduced in kidney yet a high level was maintained in liver and brain. Conti-

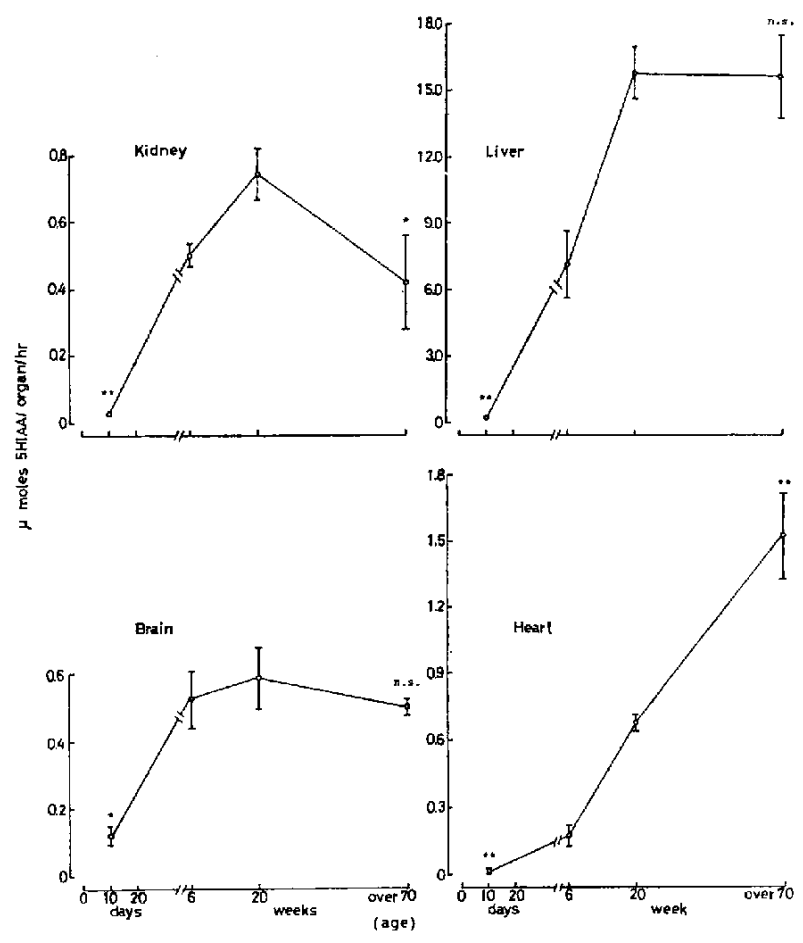

FIG. 4. Total activity of MAO in rat tissues. Calculation was carried out by multipling the specific activity by the value of protein content of particulate fraction. Each point represents the mean + S.E. of 6 to 8 different animals. ${ }^{* *} \mathrm{p}<0.01,{ }^{*} \mathrm{p}<0.05$, n.s. : non-significant, as compared to the corresponding value at 20 weeks of age. 
nuous and marked increase in the total activity of MAO was observed in the heart throughout the length of life examined.

5-Hydroxympramine (5HT) levels and enzyme activities

The level of $5 \mathrm{HT}(\mu \mathrm{g} / \mathrm{g})$ and the enzyme activities represented as $/$ moles products! gram of tissue hr are summarized in Table 2. Low levels of $5 \mathrm{HT}$ on the loth day after birth were compared with levels at 6 to 20 weeks of age. Neonatal development in 5 HT levels in brain, liver and kidney was observed. The 5 HT level reached a maximum in the brain at the 6th week, in the liver at the 20th week and continued to increase in the kidney for over 70 weeks.

TABLE 2. 5HT levels and enzyme activities per gram of rat tissues at various ages.

\begin{tabular}{|c|c|c|c|c|c|}
\hline & & 10 days $^{\mathrm{a}}>$ & 6 weeks & Age 20 weeks & over 70 weeks \\
\hline \multirow[t]{3}{*}{ Kidney } & $5 \mathrm{HT}$ & $0.083+0.000^{* * *}$ & $0.204+0.045$ & $0.200 \perp 0.024$ & $0.319 \pm 0.114$ \\
\hline & AADC & $3.53 \pm 0.67^{* *}$ & $11.07 \pm 1.35$ & $8.74 \pm 0.65$ & $4.66 \div 1.35^{* *}$ \\
\hline & $\mathrm{MAO}$ & $0.073 \leq 0.002^{* * *}$ & 0.334 .0 .081 & $0.258=0.026$ & $0.105=0.025^{* *}$ \\
\hline \multirow[t]{3}{*}{ Liver } & SHT & $0.185 \div 0.032 * *$ & $0.417 \pm 0.041$ & $0.883 \div 0.123$ & $0.882 \perp 0.259$ \\
\hline & $\mathrm{AADC}$ & $2.40 \div 0.49^{* * * *}$ & $6.50 \quad 1.0 .68$ & $7.47=0.64$ & $3.77=0.08^{* *}$ \\
\hline & MAO & $0.600+0.179^{* *}$ & $2.589+0.618$ & $1.001 \perp 0.190$ & $1.050 \pm 0.132$ \\
\hline \multirow[t]{3}{*}{ Brain } & $5 \mathrm{HT}$ & $0.249 \div 0.010^{* *}$ & $0.563 \div 0.030$ & $0.576 \pm 0.022$ & $0.537 \div 0.017$ \\
\hline & AADC & $0.281 \doteq 0.028^{* *}$ & $0.527 \perp 0.075$ & $0.548+0.076$ & $0.253 \pm 0.083^{* i}$ \\
\hline & MAO & $0.130 \doteq 0.019^{*}$ & $0.352 \div 0.054$ & $0.329 \pm 0.060$ & 0.2940 .025 \\
\hline
\end{tabular}

$5 \mathrm{HT}: \mu \mathrm{g} 5 \mathrm{HT} / \mathrm{g}$ of tissue

AADC (L-aromatic amino acid decarboxylase) : $\mu$ moles $5 \mathrm{HT} / \mathrm{g}$ of tissue $\mathrm{hr}$ MAO (monoamine oxidase) activity : $\mu$ moles $5 \mathrm{HIAA} / \mathrm{g}$ of tissue, $\mathrm{hr}$ means \pm S.E. of values from 6 to 8 rats.

a) means S.E. of $3-4$ determination from 9 to 12 rats.

** $: \mathrm{p}<0.01, *: \mathrm{p}<0.05$ as compared to the corresponding value at 20 weeks of age.

The data on AADC activity per gram of tissue of the kidney, liver and brain also demonstrated obvious neonatal increase and senescent decrease. MAO activity per gram of tissue was low on the 10 th day after birth as compared to the 6 th or 20 th week. In the senescent stage, a decrease in MAO activity was observed in the kidney. In the liver, however, the highest activity was observed at the 6th week. No age-related change in MAO activity was observed in the liver and brain after the 20th week.

\section{DISCUSSION}

In this study, neonatal increment to adult level in 5HT contents, AADC and MAO activities of the brain, kidney, liver and heart and senescent decrement of AADC in these organs were demonstrated in the rat.

Reports have termed the over 20 -month old rats as 'aged' rats (10). Although there are variations in the strain proper life span, the 72 to 94 week-old rats used in this study were taken to be in the senescent stage of life. 
Initial rise of specific activity of AADC was completed by the 3rd week after birth, in the kidney, liver and brain. This phenomenon implied that the rate of increase of AADC enzyme protein amount at this stage was faster as compared with the other soluble protein components. The specific activity of AADC in developing heart first increased, then showed a drastic decrease between 10 and 21 days, after birth. The constant total activity of AADC at this stage indicates that certain AADC-rich organelles completely develop earlier than the other AADC-lacking part of the organ. The total protein of heart was on the increase at this stage, while completion of network formation of sympathetic nerve terminals by the $12 \mathrm{th}$ day after birth and a prominent feature of mast cells in heart at carly postnatal age have been reported (11). Therefore, it is hypothesized that the growth of AADC-lacking myocardium weakened the activity of AADC, presumably localized in peripheral sympathetic nerve terminals and or in mast cells. General decrease of the specific activity of AADC in the senescent stage was first reported in this study. Since total soluble protein contents of the organs were almost constant after the 20 th week, factors responsible for the decrement in AADC activity cannot be attributed to weakening of this enzyme by other soluble proteins but rather to impaired activity of the enzyme by senescence, or by the reduced amount of enzyme protein which is undetectable.

The increment in specific activity of MAO was observed in developing kidney, liver, brain and heart, while the reduction of the specific activity of MAO was manifest only in the kidncy of aged rats. In the heart, the highest specific activity of this enzyne was otserved in the senescent stage through the life. Changes in the specific activities of these enzymes are assumed to be a manifestation of multiphasic, age-related changes of cell structures.

AADC and MAO acivities calculated as amount of product/hr/weight of organ may be parameters referable to aminc contents calculated as amount of amine/weight of tissue. Neonatal development in 5HT contents in kidney, liver and brain coincided with the increase in $\triangle A D C$ and MAO activities in these organs. These data are in agreement with that partially reported on brain $5 \mathrm{HT}(12-17)$, brain $\operatorname{AADC}(14,15,17)$, brain $\operatorname{MAO}(13,14,17)$, liver 5HT (18), liver MAO (18), kidney 5HT (19) and kidney AADC (19). Despite the considerable decrease in AADC activity in aged rats, 5 HT levels were apparently unchanged in the brain and liver. In the kidncy, rather increased 5HT levels in tissule with the reduced AADC activity were observed, presumably duc to reduced MAO activity. The reduction of AADC in the senescence appeared to have no effect on the 5HT level in situ.

A report was recently published (20), which demonstrated the low striatal dopamine (DA) level, reduced incorporation of ${ }^{3} \mathrm{H}-\mathrm{DOPA}$ into brain DA and NE, and slow turnover of hypothalamic and striatal ${ }^{3} \mathrm{H}-\mathrm{DA}$ and hypothalamic ${ }^{3} \mathrm{H}-\mathrm{NE}$ in the aged as compared with adult mice. These data strongly suggested that reduced synthesis and catabolism of monoamines exist in senescence. Reduced AADC and MAO activities per unit weight of brain in senescent rats are presumably the enzymic basis for this phenomena. An agerelated change in DOPA decarboxylase activity under a co-factor excess condition was not reported in the same paper (20). Discrepancy between these data may be the fact that the 
different species used may have a different co-factor metabolism or different mode of cofactor enzyme interaction.

The total activity of $\mathrm{AADC}$ or $\mathrm{MAO}$ in peripheral organs is related to dosimetry of amine precursors. The increase in total AADC activity in developing kidney and liver is one of the most predominent increases observed in the whole body. This may offer direct evidence for the increased peripheral AADC capacity which is suggested by the fact that the brain 5HTP uptake is minimized along with early postnatal aging (30). From the view point of the therapeutic effect of amine precursors, decrease in total liver and kidney AADC activity in the senescent animals may favor the effective utilization of amine precursors in brain, however, brain AADC activity itself declines in that stage. Thus it is postulated that change of total AADC and MAO activities may form and irregular valance of these enzyme activities as compared with that in adult ( 20 week-old) animals. Further, side effects of the amine precursor should be examined under the age-related condition. Conclusively, we would like to suggest that neonatal increase in AADC and MAO activities and senescent decrease in AADC activity in central and peripheral organs may be a manifestation of the age-related physiological state of amine metabolism and possible age-related changes in enzyme activities of tissues in humans should be considered when amine precursors are used for the purpose of therapy.

\section{REFERENCES}

1) Hoen, M.M. AND YAHR, M.D.: Neurology (Minneap.) 17, 427 (1967)

2) Sourkes, T.L.: Pharmacol. Rev. 18, 53 (1966)

3) Vogel, W.H., McFarland, H. and Prince, L. N.: Biochem. Pharmacol. 19, 618 (1970)

4) Lloyd, K. and Hornykiewicz, O.: Brain Res, 22, 426 (1970)

5) Bazelon, M., Paine, R.S., Cowie, V.A., Hunt, P., Hauck, J.C. And Mahanand, D. : Lancet 1, 1130 (1967)

6) Lovenberg, W.: Method in Enzymol. 17, p. 652, Academic Press, New York and London (1970)

7) Wurtman, R.J. And Axelrod, J.: Biochem. Pharmacol., 12, 1439 (1963)

8) Lowry, O.H., Rosebrough, N.J., Farr, A.L. A.yd Randall, R.J.: J. biol. Chem. 193, 265 (1951)

9) Bogdanski, D.F., Weissbach, H. and Udenfriend, S.: J. Neurochem. 1, 272 (1957)

10) FINCH, C.E.: Exp. geront. 7, 53 (1972)

11) De Champlain, J., Malmfors, T., Olson, L. and Sachs, Ch.: Acta physiol. scand. 80, 276 (1970)

12) KATO, R.: J. Neurochem. 5, 202 (1960)

13) Nachmias, V.T.: J. Neurochem. 6, 99 (1960)

14) Karki, N., Kuntzman, R. aNid Brodie, B.B.; J. Neurochem. 9, 53 (1962)

15) Hsia, D.Y.Y., Nishimura, K. AND Brenchley, Y.: Nature 200, 578 (1963)

16) Pepeu, G. and Giarman, N.J.: J. gen. Physiol. 45, 576 (1962)

17) Tissari, A.: Acta physiol. scand. 67, suppl. 265, 1 (1966)

18) Bojanek, J., Bozkowa, K. And Kurzepa, St.: Biol. Neonat. 9, 203 (1965/66)

19) Huang, I., Tannenbaum, S. and Hsia, D.Y.Y.: Nature 186, 717 (1960)

20) FINCH, C.E.: Brain Res. 52, 261 (1973)

21) Killoge, C. ANd Lundborg, P.: Neuropharmacology 11, 363 (1972) 